\title{
The Role of Islamic Boarding Schools in Developing Nationalism Attitudes through Character Education
}

\author{
A R S Muttaqin ${ }^{1}$, Sapriya ${ }^{2}$, M Halimi ${ }^{3}$ \\ Universitas Pendidikan Indonesia, Jalan Setiabudi 229 Bandung ${ }^{123}$ \\ bani_robani@ymail.com¹, sapriya@upi.edu²mhalimi58@upi.edu
}

\begin{abstract}
This study aims to examine the problem of nationalism attitudes that exist in Islamic boarding schools, an effort made is to strengthen the character education of students as an effort to foster an attitude of nationalism. This research was conducted at Al-Muawanah Islamic Boarding School in Bandung Regency using case studies, because Al-Muawanah is a modern Islamic boarding school that teaches character education and religion comprehensively. Data obtained from interviews, observations and documentation. The results showed that character education based on Ki Hadjar Dewantara's thinking was able to improve students' abilities from cognitive, affective and psychomotor. In addition, humanism and religious approaches in Indonesian education are interrelated aspects, so that these two aspects cannot only be applied to one. An approach that is not mechanism will make students understand the meaning of peace and morals to protect and protect others from the threats of understanding radicalism.
\end{abstract}

Keywords: Islamic boarding school; Nationalism; Character building; Student..

\section{Introduction}

Character education becomes an important issue in the world of education, it relates to the phenomenon of moral decadence that occurs in the midst of society and the increasing and varied government environment [1]. Cases of criminality, injustice, corruption, violence against children, violation of human rights, become evidence that there has been a crisis of identity and characteristics of the Indonesian nation. This condition will become even worse if the government does not immediately pursue improvement programs both long-term and short-term [2]. In an effort to achieve its national goals, the Indonesian people are always faced with various forms of challenges, threats, obstacles and disturbances, both directly and indirectly that can endanger the integrity, identity, survival of the nation and state. For this reason, it requires tenacity and resilience that contains the ability to develop national strength in aspects and dimensions of national life called state defense [3].

Mursalin and Katsir [4] education in Islamic boarding schools faces a problem, because the teaching is too narrow and encourages the growth of religious chauvinism. One form of Islamic boarding school education in Indonesia that received sharp attention after the occurrence of several radical actions in the name of religion is the islamic boarding school.

The purpose of Islamic boarding school education is to create a Muslim personality that is a personality that believes in and is devoted to God, has good character, is beneficial to the community or is beneficial to the community by becoming a servant or a servant of the community capable of standing alone, free and firm in personality, spreading religion or upholding Islam and glory Muslims in the midst of society and love science in order to develop Indonesia's personality [5]. 
The spread of radicalism in Islamic boarding schools had an impact on the difficulty of fostering an attitude of nationalism among students [6]. In the beginning there was only one people, humans were once one people (Surah Yunus 10:19), but along with the course of history, various kinds of people were formed and after that many were lost or destroyed. Islam describes in detail the terms the emergence, disappearance, and fall of various communities, commonly referred to as nations. In fact, every people have a time limit, so when the time has come, they cannot resign the item for a moment and cannot (can) also advance it (QS. Al-A'raf 7:34).

Linking Islam with nationality can be explained in two perspectives. First, from the perspective of pluralism in unity, Islam and nationalism have a positive. Second, from the perspective of universalism, nationality is against Islam. As a universal religion, Islam does not limit the allocation to certain geographical and ethnic areas [7]. The spirit of nationalism is the spirit of human groups who want to build an independent nation, based on a single soul and great solidarity, have a desire to unite and continuously be improved to unite, and create justice and togetherness [8].

There are two big groups that arise as a result of ideological resilience in Indonesia. First, a sense of nationalism tends to veer towards atheism which is contrary to the precepts of the Almighty God, like communist movements such as the Indonesian Communist Party. Second, there is a strong religious sense among Islamic religious groups but there is a tendency to replace Pancasila, such as the Indonesian Islamic State movement [9].

Research conducted by Rawantina and Arsana [10] regarding the inculcation of the value of nationalism in character education, shows the results that (1) the inculcation of the value of Nationalism and Patriotism in class X SMA Negeri 4 Sidoarjo in the form of inheritance, namely Monday's ceremony and exemplary namely the attitude and way of the teacher instilling the value of Nationalism and Patriotism; (2) Obstacles in instilling the values of Nationalism and Patriotism focus on the development of science and technology, the thinking of students who no longer care about heroic feelings and loyalty to the country, as well as parental training that influences student behavior and attitudes; (3) Efforts to overcome obstacles, based on SK and KD on the nation and state. Applied in activities based on Pancasila and based on character education; (4) The implementation of the inculcation of nationalism and patriotism values as a form of character education experiences several obstacles such as students breaking school rules, and ditching at the flag ceremony every Monday.

Research conducted by Sukatman, et al [11] shows that the implementation of nationalismreligious character education in courses for Indonesian Language Education students is still limited to learning plans, teaching materials, and learning processes. In the evaluation of learning outcomes, religious values are included in the assessment aspect but are not integrated with the values of nationalism. Instead, an assessment of nationalist character has been carried out, but not integrated with religious character. About 1\% of Indonesian language education students still adhere to radical religious-Islamic ideals, and around $0.025 \%$ of students have a nationalist "try atheist" because of frustration. This fact tells us that there are still students who are nationalists but try atheists and there are students who are religious but radical.

Research conducted by Widiatmaka [12] shows that Islamic-based schools are formal schools that implement nationalism character building, so that they have the goal of forming religious students and have a love for the motherland, because there is an assumption that love for the motherland is part of faith (not hadith but the words of some Muslims). Implementation of nationalism character building for students in Islamic-based schools 
through several ways, namely: a. Subjects of Civics Education, Al-Qur'an Education, and History, b. There are Javanese language subjects which are local languages, c. Through scouting extracurricular activities that must be followed by students, d. Intra-School Student Organization (OSIS), e. Flag ceremonies, although rarely held, f. The commemoration of the Republic of Indonesia's Independence Day which is filled with contests for students.

Research conducted by Bahri [13] regarding the role of Islamic boarding schools in Rejang Lebong Regency in preventing radicalism is very effective through strict control of the boarding school community. The commitment of boarding school leaders to consequently place its existence as tafaqquh fiddinkonci the creation of boarding schools that are always concerned in studying religious scholarship in Rejang Lebon Regency.

This research focuses on examining the role of Islamic boarding schools in fostering nationalism through a strategy of strengthening humanism and religious-based character education initiated by Ki Hadjar Dewantara.

\section{Method}

Creswell [14] qualitative research are methods for exploring and understanding the meaning that some individuals or groups of people ascribe to social or humanitarian problems. The research method used in this research is, case studies, because Al-Muawanah is a modern Islamic boarding school that teaches character education and religion comprehensively. Creswell says that case studies are research strategies in which researchers investigate carefully a program, event, activity, process, or group of individuals. This research was carried out at AlMu'awanah Modern Islamic Boarding School Cidawolong Majalaya, Address: Kp. Cidawolong IV, RT.01 / RW.19, Biru, Majalaya, Bandung, West Java 40382. Phone: (022) 85961408. In this study the research subject is the manager of Al-Mu'awanah Modern Islamic Boarding School, Teacher at Pondok Al-Mu'awanah Modern Islamic Boarding School, and students at Al-Mu'awanah Modern Islamic Boarding School. Data collection techniques using interviews, observation and documentation [15]. The process of data analysis in this research will be carried out continuously from the beginning to the end of the study, both in the field and outside the field. Data analysis takes place simultaneously with the data collection process. Among these are data reduction, data presentation and conclusions / verification.

\section{Result And Discussion}

One important problem that is being faced by this nation is the waning spirit of nationalism and patriotism among the younger generation [16]. Various problems that arise as a result of the waning spirit of nationalism and patriotism have occurred lately, many young generations are disoriented and involved in an interest that is only selfish. Another problem that arises in fostering an attitude of nationalism in education is delivered by Maftuh [17] which states that there are five challenges of the Indonesian nation in growing an attitude of nationalism, namely: 1) the values of Pancasila seem to be still not grounded, still not practiced well by the Indonesian people. Pancasila seems to only be a symbol, without being implemented in a real way both at the level of state life and at the level of community life, 2) the life of the Indonesian people, especially the younger generation in this globalization era has a very strong influence from outside cultural values, so that a lot of attitudes and behavior that are not 
in line with the values of Pancasila, 3) the values of nationalism are also seen by some as experiencing erosion at this time, especially among the younger generation.

Furthermore, 4) the development of religious understanding that does not consider the importance of nationalism and the nationhood of Indonesia, and more views the importance of universalism. Proponents of this understanding also reject democracy as a system of government that is seen as good and in the end does not view Pancasila as an ideology that is important and appropriate for our nation. This understanding is not only developing in the community, but also developing among students in tertiary institutions; and, 5) the role of education still needs to be questioned in both the formal and non-formal education pathways in internalizing the values of Pancasila, including the values of nationalism to the Indonesian people, especially to the younger generation.

Based on research conducted, Al-Mu'awanah Modern Islamic Boarding School did the reactualization of character education initiated by Ki Hadjar Dewantara on actions that were not well taken by teachers, students and parents of students. Marwah, Syafe'i and Sumarna [18] stated violations after violations continued to emerge over time. The case that occurred was a teacher who committed immoral acts with his own students, then as for a case that occurred in another area where a student had the heart to persecute his own teacher even to death, besides that there were parents who were less wise in responding to their children's problems with do rude actions to the teacher. The three elements in education, namely students, teachers and parents actually take actions that are not in accordance with the objectives of education. This phenomenon is based on the failure of character education which prioritizes cognitive abilities and provides affective and psychomotor abilities.

Education is one of the efforts to take students towards maturity in various aspects. Ramdhani [19] states that schools have two main functions namely the place of education and socialization institutions. Based on these two functions, the influence of the school on students is not only limited to the transfer of knowledge, but the atmosphere of the school environment and the applied education system will also affect the development of student personality functions. Moral learning strategies are very necessary because of the many moral behaviors among students such as ditching, cheating on exams or daily tests, fighting among friends.

\subsection{Humanist and Religious Approaches in Education}

Based on research conducted at Al-Mu'awanah Modern Islamic Boarding School shows that teaching character education uses a humanist and religious approach, thus making students feel comfortable in carrying out activities related to citizenship behavior.

Humanist education emphasizes the importance of human existence, in the sense of helping humanity be more humane, more cultured, as a fully developed human being. According to Ki Hajar Dewantara concerning creativity, taste and initiative [20]. Ki Hadjar Dewantara in his idea of education does not directly reveal religuising education, but in some perspectives, education experts such as Suparlan and Kumalasari consider that life progress meant in the educational goals initiated by Ki Hadjar Dewantara is the progress of life both physically and mentally. Based on this, the humanism and religious approach in Indonesian education are interrelated aspects, so that these two aspects cannot only be applied either.

Islam recognizes the differences of people according to their religious affiliations. Christians are called the people (community) of Jesus, the Jews are called the people of Moses, just as Muslims form the people of the Prophet Muhammad. Ibrahim himself was called the people who obeyed God (QS. Al-Nahl 16: 120), and each people has one trap of 
worship chosen by God for them, and for each of us we have committed a worship (QS. AlHajj 22:34).

\subsection{The Idea of the Among Educational System at Al-Mu'awanah Modern Islamic Boarding School}

The re-actualization of Ki Hadjar Dewantara's character education based on the integration of a humanist and religious approach needs to be implemented in an education system that according to Ki Hadjar Dewantara is the Among educational system which is an educational system that is family-minded and based on nature and independence. In this system each educator must spend as much as 24 hours every day to provide services to students. Among's education system is based on how it is called Tutwuri Handayani. Educational orientation is student centered which means education must be developed in the interests of students, not in the interests and abilities of educators.

Al-Mu'awanah Modern Islamic Boarding School integrating humanist and religious approaches needs to be done by involving families, communities and schools. These three parties constitute a synergy to optimize character education based on a humanism and religious approach. According to Ki Hadjar Dewantara education as guidance in the life of growing children, meaning that education guides all natural forces that exist in these children, so that they as humans and as members of the community can achieve the highest safety and happiness [21].

Rahardjo [22] states that independent human beings are the goals of Ki Hadjar Dewantara's education, independence both physically, mentally, and spiritually. Personal independence is limited by the peaceful order of shared life, and this supports attitudes such as harmony, harmony, deliberation, tolerance, togetherness, democracy, responsibility, and discipline. An independent human being is someone who is able to develop fully and harmoniously from all aspects of his humanity and who is able to respect and respect the humanity of everyone.

\subsection{Dimensions of Character Education Learning}

Suparlan [23] states that Ki Hadjar Dewantara's view of learning appears in the concept of the Tri Education Center, that students not only learn in school but also in families and communities (in the realm of youth). Family nature education will educate children as well as possible which includes physical and spiritual. Family conditions greatly affect educational behavior, especially help-help in the family, caring for sick relatives, togetherness in maintaining cleanliness, health, peace and togetherness in various issues that are very sought after in the family.

Ki Hajar Dewantara implied four competencies that must be possessed by an educator. First, pedagogical competence, with the motto of Tut Wuri Handayani, from behind an educator must be able to provide encouragement and direction. Then, Ing Madya Mangun Karsa when among students, educators must create initiatives and ideas. Second, personality competence, like its motto, Ing Ngarsa Sung Tulada, means that when the educator is ahead, a teacher must set an example. Third, social competence, namely educators have advantages in relationships with students, parents and the community. Fourth, professional competence, namely educators must have a professional appearance physically, intellectually, social relations, personality, values and spirituality, and be able to be a motivator.

Associated with efforts to attain moral individuals as mentioned above, based on the Islamic paradigm of education, namely the creation of people who carry out all their daily 
activities as a form of submission to Allah, it is clear that monotheism is the basis. For this reason, the first step that must be taken is the cultivation of aqidah that is strong and straight from an early age. With a strong faith, someone will not be easily swayed by any undermining. He has a strong stronghold to face the persuasion and temptations of the world. In this case, the role of the family becomes very urgent, especially during the first six years which in psychology is called the golden age, and in the teenage phase.

\section{Conclusions}

Character education at Al-Mu'awanah Modern Islamic Boarding School uses humanism and religious approaches, so students are able to develop cognitive, affective and psychomotor abilities. Ki Hadjar Dewantara's character education through the concept of Among education is taught comprehensively by involving parents, schools and the community. Character education based on humanism and religion can suppress counter productive actions with the spirit of nationalism. Islamic values need to be included in the teaching of character education, because the values of Islam and character are interrelated and complementary aspects.

\section{References}

[1] Erkilic, Mualla, and S Durak. "Tolerable and inclusive learning spaces: An evaluation of policies and specifications for physical environments that promote inclusion in Turkish primary schools." International Journal of Inclusive Education 17, no. 5. 2013, 462-479.

[2] N. Ainiyah. "Pembentukan Karakter Melalui Pendidikan Agama Islam." Al-Ulum 13, no. 1. 2013, 25-38.

[3] Satori, Akhmad, and E. Kusmayadi. "Pendidikan Bela Negara Bagi Santri Pesantren di Cikalong Kabupaten Tasikmalaya." JPPM (Jurnal Pengabdian dan Pemberdayaan Masyarakat) 2, no. 2. 2018, 157-163.

[4] Mursalin, Ayub, and I Katsir. "Pola Pendidikan Keagamaan Pesantren dan Radikalisme: Studi Kasus Pesantren-pesantren di Provinsi Jambi." Kontekstualita: Jurnal Penelitian Sosial Keagamaan 25, no. 2. 2010, 37096.

[5] A Muqit "Profesionalisme Kiai dalam Pengelolaan Pondok Pesantren dalam Konteks Kemodernan." Jurnal Pendidikan Islam Indonesia 2, no. 2. 2018, 139-158.

[6] S. Z. Zubaedi, M. Mulyadi, A. Amin, Z. Dali, and A. W. Asiyah. "The Construction of Religious Moderation Values in Islamic Boarding Schools (Pesantren): Efforts to Prevent Radicalism in Indonesia." Journal of Talent Development and Excellence 12, no. 2s. 2020, 3613-3623.

[7] A. Azman. "Nasionalisme Dalam Islam." Al Daulah: Jurnal Hukum Pidana dan Ketatanegaraan 6, no. 2. 2018, 266-275.

[8] M. Mugiyono. "Relasi Nasionalisme dan Islam Serta Pengaruhnya Terhadap Kebangkitan Dunia Islam Global." Jurnal Ilmu Agama: Mengkaji Doktrin, Pemikiran, Dan Fenomena Agama 15, no. 2. 2014, 97-115.

[9] S. Sukatman, F. Husniah, A. Taufiq, E. S. Widayati, A. Widjajanti, S. Siswanto, and F. N. Murti. "Pendidikan Karakter Nasionalis-Religius bagi Mahasiswa Pendidikan Bahasa Indonesia di Universitas Jember Studi Kasus." Belajar Bahasa: Jurnal Ilmiah Program Studi Pendidikan Bahasa dan Sastra Indonesia 4, no. 1. 2019, 136-148.

[10] I. Rawantina and I. Novitasari. "Penanaman nilai nasionalisme dan patriotisme untuk mewujudkan pendidikan karakter pada mata pelajaran pendidikan kewarganegaraan siswa kelas x sma negeri 4 sidoarjo." Kajian Moral dan Kewarganegaraan 1, no. 1, 2013. 39-54.

[11] Op.Cit, Sukatman, et.al (2019) 
[12] P. Widiatmaka. "Pembangunan Karakter Nasionalisme Peserta Didik Di Sekolah Berbasis Agama Islam." JPK (Jurnal Pancasila dan Kewarganegaraan) 1, no. 1, 2016. 25-33.

[13] S. Bahri. "Peran Pondok Pesantren dalam Mencegah Paham Radikalisme di Kabupaten Rejang Lebong." Kaganga: Jurnal Pendidikan Sejarah Dan Riset Sosial-Humaniora 1, no. 2, 2018. 107121.

[14] J.W. Creswell. "Research design pendekatan kualitatif, kuantitatif, dan mixed." Yogyakarta: Pustaka Pelajar, 2010.

[15] H. Ramdhani "Pencegahan White Collar Crime melalui Kebijakan Non Penal." Jurnal Somasi 1, no. 1, 2014, 19-31.

[16] J.E. Ketelaar. "Rude Awakenings: Zen, the Kyoto School, and the Question of Nationalism." 1997, 214-217.

[17] B Maftuh. "Internalisasi nilai-nilai Pancasila dan nasionalisme melalui Pendidikan Kewarganegaraan." Jurnal Educationist 2, no. 2, 2008, 134-144.

[18] Marwah, S. Shafa, M. Syafe'i, and E. Sumarna. "Relevansi Konsep Pendidikan Menurut Ki Hadjar Dewantara dengan Pendidikan Islam." TARBAWY: Indonesian Journal of Islamic Education 5, no. 1, 2018, 14-26.

[19] H Ramdhani. "Studi Komparatif Kurikulum Pendidikan Politik Di Perguruan Tinggi Negeri." PROSIDING SENASPOLHI 1, no. 1, 2019.

[20] D Kumalasari. "Konsep pemikiran Ki Hadjar Dewantara dalam pendidikan taman siswa (tinjauan humanis-religius)." ISTORIA: Jurnal Pendidikan dan Sejarah 8, no. 1, 2010, 47-59.

[21] E. Yanuarti "Pemikiran pendidikan ki. Hajar dewantara dan relevansinya dengan kurikulum 13." Jurnal Penelitian 11, no. 2, 2017, 237-265.

[22] Rahardjo, Biografi Singkat Ki Hajar Dewantara, 1889-1959. Yogyakarta: Garasi, 2009.

[23] H. Suparlan "Filsafat pendidikan Ki Hadjar Dewantara dan sumbangannya bagi pendidikan indonesia." Jurnal Filsafat 25, no. 1, 2015, 56-74. 